\title{
Aracy Lopes da Silva
}

\author{
Luís Donisete Benzi Grupioni \\ Doutorando do Departamento de Antropologia - USP
}

Aracy foi uma das pessoas mais carinhosas que já conheci. Tinha um sorriso cativante, uma alegria que contagiava a todos, um jeito sempre doce e atencioso de se relacionar com as pessoas. Seu modo meigo e leal de ser cativou amizades espalhadas por todo o país e a notícia de que ela não está mais entre nós deixa-nos consternados.

Aracy foi minha primeira professora de antropologia. Ela era amável e generosa, mas também rigorosa e exigente. Todos nós que fomos seus alunos, aprendemos muito com ela, na sala de aula e fora dela. Aprendemos muito com seus longos comentários a nossos textos, seus carinhosos conselhos e incentivos para que vencêssemos nossas dificuldades. Ela nos desafiava a nos aperfeiçoarmos, a melhorarmos nossa escrita, a usarmos com precisão conceitos e teorias, a lermos mais e novos autores, a evidenciarmos nossos dados, a gostarmos do que estávamos fazendo. Sentíamos que ela apostava em nosso crescimento enquanto intelectuais e profissionais em formação na antropologia, mas também enquanto seres humanos, com padrões éticos e honestos, que deviam permear não só nossos textos, mas também nossas vidas e nossos relacionamentos.

Aracy gostava de ser professora. Tinha paixão pelas aulas e por seus alunos. Preocupava-se conosco e estava sempre pronta a consolar e a incentivar. A doçura com que nos tratava, numa conversa ou numa leitura de algum texto ou trabalho, não a impedia de ser exigente e de cobrar de nós o melhor. Lembro o quanto ela apreciava quando um grupo de alunos se reunia em seu redor ao final de cada aula, a ponto de cunhar uma expressão própria para esse momento: "a sobremesa". 
Aracy gostava de conversar, de saber como andava nossa vida, o que estávamos fazendo, que planos estávamos construindo. No ritmo de vida atribulada que todos nós levamos, muitas vezes me vi fazendo listas de assuntos que precisava discutir com ela, e quase sempre mais da metade dos assuntos ficava para outra oportunidade. Era incomum tratarmos apenas de temas de trabalho, porque em tudo que ela fazia havia emoção, havia sentimentos, havia interesse não só pelo lado profissional, mas também pelo lado pessoal. E foi assim que ela conquistou inúmeros amigos na antropologia.

Aracy teve um papel importante na minha formação e na de meus colegas, influenciando positivamente na escolha de temas de pesquisa e de abordagens teóricas. A certa altura, me vi não apenas como seu aluno, mas como parceiro de trabalho, e penso que talvez não seja à toa que, mais tarde, tenha me identificado com suas preocupações em torno de questões voltadas à educação indígena e à difusão de informações sobre os índios. Junto com alguns colegas, fundamos o Mari - Grupo de Educação Indígena da USP -, um grupo de pesquisa na interface antropologia e educação, voltado à reflexão dos processos de introdução da educação formal em áreas indígenas. Foi ali que trabalhamos mais próximos, que aprendemos a lidar um com o outro. Ali ela depositou muitas energias, mas também colheu frutos que a animavam a pensar em novos projetos e a encarar novos desafios. O Mari não lhe era um fardo, ao contrário, ela sempre dizia como era gostoso participar das reuniões, como se sentia bem em estar ali.

Aracy foi uma pioneira na área da educação indígena, tanto no sentido de pensar o potencial da escola em terras indígenas a favor dos índios quanto de tornar esta temática teoricamente relevante na academia. Esta foi uma de suas militâncias em prol de uma melhor sorte para os índios. E seu comprometimento político com esta temática sempre esteve ancorado no esforço de pensar teoricamente a questão. Além de escrever e orientar pesquisas sobre este tema, propôs em 1995 a elaboração de um amplo projeto de pesquisa temática para a Fapesp, Antropologia, História e Educação: a questão indígena e a escola, que, de 1996 a 1999, congregou estudantes e professores da USP e Unicamp. Em seus últimos meses de 
vida, Aracy finalizou quatro coletâneas, algumas delas já no prelo, com os resultados deste projeto.

Aracy tinha como uma de suas preocupações a difusão de informações sobre as sociedades indígenas para um público mais amplo que o da academia. De 1992 a 1996, ela coordenou uma série de cursos de extensão universitária que o Mari ofereceu para professores da rede pública de São Paulo sobre a questão indígena no Brasil. Desse esforço de ampliar a divulgação de conhecimentos sobre os índios, nasceu o projeto de organizarmos o livro A temática indígena na escola, para o qual convidamos diversos colegas de diferentes universidades. Lançado em 1995, este livro era uma versão ampliada e atualizada de um outro, que Aracy havia organizado quando era responsável pelo Setor de Educação da Comissão Pró-Índio de São Paulo (A questão indígena na sala de aula, 1987). São também de sua autoria, um livro paradidático (Índios, 1988) e um de literatura infantil (Histórias de verdade, 1984), recentemente reeditado.

Aracy também teve atuação marcante na área das políticas públicas de educação indígena. Foi representante da Associação Brasileira de Antropologia no Comitê de Educação Escolar Indígena do MEC, colaborando na formulação de documentos e propostas de ações, apontando, sempre de forma crítica e lúcida, as deficiências da ação governamental. Fui escolhido por ela como seu suplente, e muitas foram nossas discussões sobre os limites dessa participação no governo. Numa de nossas últimas conversas, ela avaliou que fôra um momento importante este de inscrever preocupações antropológicas e indigenistas nas políticas públicas dirigidas aos índios, mas que agora era preciso um novo esforço de reflexão acadêmica sobre os rumos da escola indígena, a ser feito na universidade. Anunciou que este era um de seus planos para o futuro.

Aracy e eu mantínhamos contato freqüente, senão pessoalmente, por telefone, e-mail ou bilhetes. Com sua mudança para São Carlos e seus novos compromissos na Unicamp, passamos a nos ver menos. Até que, por ocasião de uma reunião do MARI na USP, combinamos de nos 
encontrar. Falamos de tudo um pouco, mas somente a certa altura da conversa chegamos ao ponto: ela me disse que achava que eu estava chateado com ela, e eu respondi que achava o contrário. Rindo, combinamos um jogo: primeiro ela e depois eu diríamos o que achávamos que estava incomodando um ao outro. Nós dois perdemos o jogo, pois chegamos à conclusão que os dois estavam errados, que não havia incômodo algum, a não ser o da falta de contato. Saímos daquele encontro com a alma lavada, com a certeza de que a franqueza era um dos pilares de nosso relacionamento, mas sem saber que aquela seria a última vez que nos encontraríamos.

Aracy, logo em seguida, entraria "num período de transição, uma época de passagem, de crise de vida, de períodos vulneráveis”, como ela mesma me descreveu em um de seus últimos $e$-mails.

Aracy deixa em nós uma imensa e profunda saudade, um sentimento de desalento diante de sua abrupta ausência, uma sensação de perda e de vazio. Por ser tão doce e cheia de vida, não posso deixar de pensar que ela partiu cedo demais. 